\title{
The Estimation of Serum Bilirubin
}

\author{
By J. PATTERSON, J. SWALE AND CORA MAGGS \\ Department of Chemical Pathology, Charing Cross Hospital Medical School, London
}

\author{
(Received 18 January 1952)
}

The more important methods used and the problems involved in the estimation of bilirubin in serum have been adequately reviewed in recent times by Lemberg \& Legge (1949) and by King \& Coxon (1950). The methods are of two types: those based essentially on the original van den Bergh technique for the so-called 'indirect reaction' (Thannhauser \& Andersen, 1921; Haslewood \& King, 1937), and those which promote coupling between van den Bergh reagent and bilirubin without precipitation of proteins. In the latter type, special catalysts or accelerators are employed, e.g. sodium benzoate and caffeine (Jendrassik \& Cleghorn, 1936), urea and caffeine (Rappaport \& Eichhorn, 1943), thereby avoiding the use of alcohol or other protein precipitants. Alternatively, alcohol is used in relatively low concentration in the presence of diluted serum in such a way that no precipitation occurs (Malloy \& Evelyn, 1937).

The main defect of the first type of method lies in the fact that, in the course of protein precipitation and its subsequent removal, considerable loss of either bilirubin or azobilirubin is incurred. On the other hand, methods of the second class suffer from the fact that the clarity of the final coloured solutions leaves much to be desired. In some cases, indirect bilirubin fails to react completely in a reasonable space of time (Gray \& Whidborne, 1946). King \& Coxon (1950), dissatisfied with the performance of the non-precipitation methods, have reverted to the original type of procedure with a modification which employs a higher dilution of serum and reagents in the presence of ethanol than is customary, thereby minimizing the loss of azobilirubin.

We have investigated the van den Bergh reaction to see whether we could arrive at conditions whereby real clarity could be achieved in the final solution prepared for colorimetric analysis without recourse to any step involving separation of proteins, and at the same time utilize a reaction which would proceed rapidly to completion in all types of case, no matter what the form of bilirubin present.

Rapid coupling of indirect bilirubin with the diazo reagent is achieved by use of urea-ethanol solutions in conditions which introduce only slight opacity, representing a very small degree of protein precipitation. This cloudiness completely disappears when concentrated phenol solution is added. Employment of phenol in connexion with the develop- ment of a diazo colour requires considerable care. Regard must be paid to the necessity of inactivating the excess of diazo reagent before the phenol is added, and also to avoidance of the formation of any pink oxidation product from the phenol used.

Following the observation of Lees (1950) that azide would react with the diazonium component of the Griess-Ilosva reagent to diminish the colour intensity produced by subsequent coupling with 1 naphthylamine, azide was tried as a simple means of inactivating excess of the van den Bergh reagent and was found highly effective. The addition, therefore, of a trace of azide, and the removal of excess of nitrous acid by the usual sulphamate addition, overcome the objections to the introduction of phenol into the van den Bergh reactions, and allows the completion of a method which in practice has proved satisfactory in its application to all clinical cases so far investigated.

\section{METHOD}

\section{Reagents}

Diazo reagent. Solution $A, 1 \mathrm{~g}$. of sulphanilic acid in 11 . $0.175 \mathrm{~N}-\mathrm{HCl}$. Solution $B, 0.5 \mathrm{~g}$. $\mathrm{NaNO}_{2}$ in $100 \mathrm{ml}$. of aqueous solution. $10 \mathrm{ml}$. of $A$ are mixed with $0.3 \mathrm{ml}$. of $B$. After $5 \mathrm{~min} .1 \mathrm{ml}$. of $1.5 \%(\mathrm{w} / \mathrm{v})$ ammonium sulphate is added, and the reagent used after standing a minimum of $3 \mathrm{~min}$. A corresponding 'blank' reagent is made by substituting distilled water for solution $B$ in the dizao reagent.

Ethanol-urea solution. With the aid of heat, $25 \mathrm{~g}$. of urea (A.R.) are dissolved in $100 \mathrm{ml}$. of $85 \%$ (v/v) ethanol, filtered while still warm and kept in an incubator to prevent crystallization of urea.

Sodium azide. Solid.

Phenol solution. To 90 parts by weight of freshly redistilled pure phenol are added 10 parts of water with stirring.

Acid buffer solution. $29 \cdot 41 \mathrm{~g}$. of sodium citrate $\left(\mathrm{Na}_{3} \cdot \mathrm{C}_{6} \mathrm{H}_{5} \mathrm{O}_{7} \cdot 2 \mathrm{H}_{2} \mathrm{O}\right.$ A.R.) are dissolved in $0 \cdot 2 \mathrm{~N}-\mathrm{HCl}$ to a volume of $500 \mathrm{ml}$. $200 \mathrm{ml}$. of this buffer are made up to $500 \mathrm{ml}$. with distilled water.

Neutral buffer solution. Sodium citrate $(5 \cdot 0 \mathrm{~g}$. A.R.) is dissolved in distilled water and made up to $100 \mathrm{ml}$.

\section{Procedure}

In each of two glass-stoppered test tubes of $10 \mathrm{ml}$. capacity place $0.5 \mathrm{ml}$. of serum. To the first add $0.5 \mathrm{ml}$. of van den Bergh diazo reagent-sulphamate solution, and to the second, add $0.5 \mathrm{ml}$. of the corresponding blank reagent. Place both tubes in a beaker containing ice-cooled water. 
Add to each $2.2 \mathrm{ml}$. of ethanol-urea solution, followed by $0.2 \mathrm{ml}$. of $\mathrm{CHCl}_{3}$. Mix and keep ice-cooled for $10 \mathrm{~min}$. Add a tiny fragment of azide (about $0.2 \mathrm{mg}$.) to each tube. Shake to dissolve, and then add $0.1 \mathrm{ml}$. of neutral citrate buffer and mix. Finally add $2.5 \mathrm{ml}$. of the phenol solution. Stopper each tube securely and shake vigorously until a clear solution is obtained. Read the van den Bergh colour against that produced by the blank reagent in the photoelectric colorimeter using a green filter. (In routine work the Biochem absorptiometer, standard test tubes, and a Chance green filter OGl (maximum transmission 520-540 $\mathrm{m} \mu$.) have been used, but the data obtained have been further substantiated by the supplementary use of the Spekker absorptiometer with Ilford filter 604.)

Where the serum bilirubin exceeds $8 \mathrm{mg} . / 100 \mathrm{ml}$. the determination is repeated using serum suitably diluted with acid buffer.

\section{Calibration}

Pure bilirubin (Hoffman-La Roche) was used as the standard preparation for calibration purposes. Compared with other readily available commercial samples, it had a

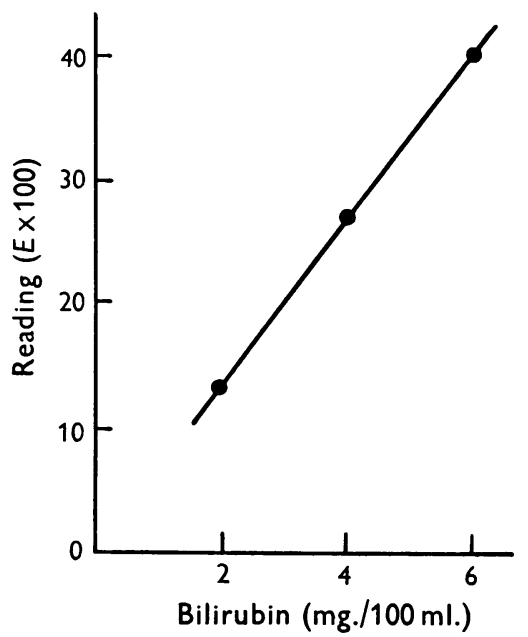

Fig. 1. Calibration curve. Spekker absorptiometer with Ilford filter 604 and $1 \mathrm{~cm}$. cells.

higher chromogenic power, which could not be increased by attempts at further purification using chromatographic methods and recrystallization. Moreover, it was previously used in this type of work and found satisfactory by earlier workers (Malloy \& Evelyn, 1937; Gray \& Whidborne, 1946).

Pure bilirubin (10 mg.) was dissolved in $100 \mathrm{ml}$. of $\mathrm{CHCl}_{3}$, and graded dilutions in $\mathrm{CHCl}_{3}$ were prepared from this stock.

The technique used in calibration was exactly the same as for the test method, except for using $0.2 \mathrm{ml}$. of bilirubin solution in place of the pure $\mathrm{CHCl}_{3}$ and acid citrate buffer in place of serum. Fig. 1 shows the relation between colour density and concentration of bilirubin. Because of the sensitivity of the azobilirubin colour to changes in $\mathrm{pH}$, adequate control of this factor is only assured if the colour developed in the calibration technique can be accurately identified with that produced in the test method. Figs. 2 and 3 record the spectral absorption curves obtained, respectively, from pure bilirubin and from a jaundiced serum of approximately equivalent bilirubin concentration, using on the one hand a water blank and on the other a yellow blank prepared as indicated in the above procedure. It is shown that a close identity exists between the corresponding curves of these two charts.

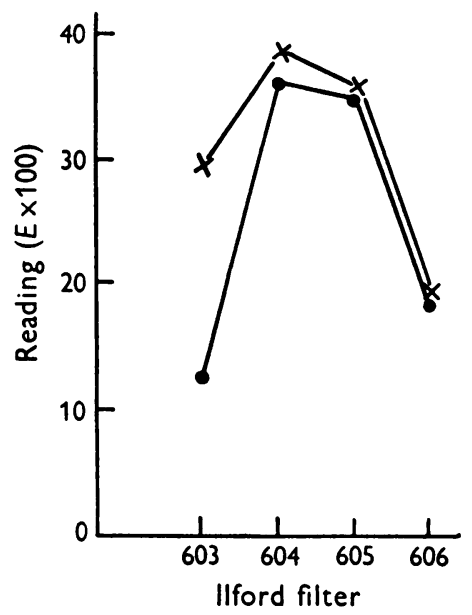

Fig. 2. Spectral absorption curves of azobilirubin colours produced in the calibration method from pure bilirubin. $x-x$, azobilirubin read against a colourless blank; - - a azobilirubin read against the corresponding yellow blank. Spekker absorptiometer with Ilford filter 604 .

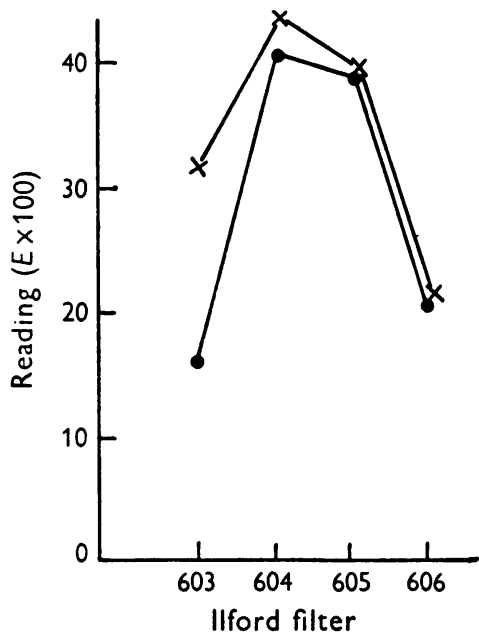

Fig. 3. Spectral absorption curves of azobilirubin colours produced from serum bilirubin. $x-x$, azobilirubin read against a colourless blank; -0 , azobilirubin read against the corresponding yellow blank. Spekker absorptiometer with Ilford filter 604 .

\section{RESULTS}

The reproducibility of results with sera was examined by the performance of a series of five estimations on an individual sample. The following values by the routine method were obtained: $3 \cdot 32,3 \cdot 25$, 
$3 \cdot 36,3 \cdot 25,3 \cdot 32 \mathrm{mg}$. bilirubin/ $100 \mathrm{ml}$., giving a mean value of $3.30 \mathrm{mg} . / 100 \mathrm{ml}$. and a standard deviation from the mean of $0.03 \mathrm{mg} . / 100 \mathrm{ml}$.
Time factor in colour development. In order to determine the time required for full development of colour under the conditions of the test, a number of

Table 1. Recovery of bilirubin added to sera

(Zero values in first column indicate $<0 \cdot 1$.)

\begin{tabular}{|c|c|c|c|c|}
\hline $\begin{array}{c}\text { Serum } \\
\text { bilirubin } \\
\text { (mg./100 ml.) }\end{array}$ & $\begin{array}{c}\text { Bilirubin } \\
\text { added } \\
\text { (mg./100 ml.) }\end{array}$ & $\begin{array}{l}\text { Total bilirubin } \\
\text { found } \\
\text { (mg./100 ml.) }\end{array}$ & $\begin{array}{l}\text { Added bilirubin } \\
\text { recovered } \\
\text { (mg./100 ml.) }\end{array}$ & $\begin{array}{c}\text { Recovery } \\
(\%)\end{array}$ \\
\hline \multicolumn{5}{|c|}{ Readings on Biochem absorptiometer, Chance filter OG 1} \\
\hline 0 & $\mathbf{3 . 6 7}$ & 3.80 & - & 104 \\
\hline 0 & $4 \cdot 54$ & $4 \cdot 37$ & - & 97 \\
\hline 0 & $6 \cdot 05$ & $5 \cdot 83$ & - & 96 \\
\hline 0 & $7 \cdot 64$ & $\mathbf{7 \cdot 3 6}$ & - & 96 \\
\hline 0.55 & $4 \cdot 00$ & $4 \cdot 62$ & 4.07 & 102 \\
\hline $1 \cdot 08$ & 4.00 & $5 \cdot 20$ & $4 \cdot 12$ & 103 \\
\hline 0.60 & 3.67 & 4.31 & $3 \cdot 71$ & 101 \\
\hline
\end{tabular}

Readings on Spekker absorptiometer, Ilford filter 604

$\begin{array}{llllr}0 & 3 \cdot 55 & 3 \cdot 56 & - & 100 \\ 0 & 3 \cdot 67 & 3 \cdot 83 & - & 104 \\ 0 \cdot 40 & 3 \cdot 67 & 4 \cdot 00 & 3 \cdot 60 & 98\end{array}$

Table 2. Serum bilirubin values $(\mathrm{mg} . / 100 \mathrm{ml}$.) derived from azobilirubin colour produced after varying reaction times

(Readings on Spekker absorptiometer, Ilford filter 604.)

\begin{tabular}{|c|c|c|c|c|c|}
\hline \multirow[b]{2}{*}{ Type of serum } & \multicolumn{5}{|c|}{ Reaction time (min.) } \\
\hline & 2 & 5 & 10 & 20 & 45 \\
\hline $\begin{array}{l}\text { Cord-blood serum from jaundiced baby; } \\
\text { indirect reacting }\end{array}$ & - & - & $8 \cdot 6$ & $8 \cdot 7$ & - \\
\hline $\begin{array}{l}\text { Toxic hepatitis; latent jaundice; } \\
\text { indirect reacting }\end{array}$ & - & - & $1 \cdot 80$ & 1.80 & - \\
\hline Infective hepatitis; direct reacting & $6 \cdot 0$ & $6 \cdot 4$ & $6 \cdot 2$ & 6.4 & - \\
\hline Cord-blood serum from jaundiced baby; & - & - & $6 \cdot 1$ & $6 \cdot 1$ & $6 \cdot 1$ \\
\hline
\end{tabular}

Table 3. Serum bilirubin estimated at varying dilutions using acid citrate buffer and serum (of negligible bilirubin content) as diluents

(Readings made with Biochem absorptiometer.)

\begin{tabular}{|c|c|c|c|c|}
\hline \multirow[b]{2}{*}{ Type of serum } & \multicolumn{2}{|c|}{ Diluted with citrate } & \multicolumn{2}{|c|}{ Diluted with serum } \\
\hline & Dilution & $\underset{\text { (mg./100 ml.) }}{\text { Bilirubin }}$ & Dilution & $\begin{array}{c}\text { Bilirubin } \\
\text { (mg./100 ml.) }\end{array}$ \\
\hline Obstructive jaundice & $\begin{array}{l}1 \text { in } 4 \\
1 \text { in } 6 \\
1 \text { in } 8\end{array}$ & $\begin{array}{l}23 \cdot 5 \\
24 \cdot 4 \\
24 \cdot 8\end{array}$ & $\begin{array}{l}1 \text { in } 4 \\
1 \text { in } 6 \\
1 \text { in } 8\end{array}$ & $\begin{array}{l}24 \cdot 9 \\
24 \cdot 0 \\
23 \cdot 7\end{array}$ \\
\hline Toxic jaundice & $\begin{array}{l}1 \text { in } 2 \\
\text { Undiluted }\end{array}$ & $\begin{array}{l}2 \cdot 86 \\
2 \cdot 75\end{array}$ & - & $=$ \\
\hline Obstructive jaundice & $\begin{array}{l}1 \text { in } 2 \\
1 \text { in } 4\end{array}$ & $\begin{array}{l}7 \cdot 04 \\
6 \cdot 73\end{array}$ & - & - \\
\hline
\end{tabular}

Recoveries. The percentage recovery was estimated by adding known amounts of bilirubin in the form of chloroform solution to the serum mixture. This addition can be done at any stage up to and including the application of the urea-ethanol solution. Selected sera containing negligible amounts of bilirubin (less than $0.1 \mathrm{mg} . / 100 \mathrm{ml}$.), and also normal sera, were used. The results are shown in Table 1. estimations on different types of jaundiced sera were made, allowing varying intervals between the addition of the urea-ethanol and that of the azide. Table 2 records some typical results, which show that a $10 \mathrm{~min}$. period is adequate for the full reaction to take place.

A number of jaundiced sera were examined, using as diluents the citrate buffer on the one hand and serum containing a negligible amount of bilirubin on 
the other. The data in Table 3 show that concordant estimations are obtained at widely differing dilutions, and that the buffer does not introduce error in the final values when replacing serum.

Analytical data are presented in Tables 4 and 5 to show the general relationship of the results obtained

\section{Table 4. Estimations of bilirubin in direct sera}

(Indices indicate dilution factors. $A$, read on Biochem absorptiometer, Chance filter OG 1; $B$, read on Spekker absorptiometer, Ilford filter 604, except for the Malloy \& Evelyn (1937) method when 605 filter was used. The calibration curve used for the Malloy \& Evelyn determinations was constructed as described by the original authors with the exception that methanol was used in place of ethanol. On account of the different effects of the two alcohols upon the azobilirubin colour tone, the colour of the calibration solutions is not so accurately reproduced in those of the test method if the same alcohol is not used for both.)

$\begin{array}{rccc}\text { Case } & \begin{array}{c}\text { Present } \\ \text { method } \\ \text { (mg./100 ml.) }\end{array} & \begin{array}{c}\text { Malloy \& } \\ \text { Evelyn }(1937) \\ \text { method } \\ \text { (mg./100 ml.) }\end{array} & \begin{array}{c}\text { King \& } \\ \text { Coxon (1950) } \\ \text { method } \\ \text { (mg./100 ml.) }\end{array} \\ 1 & 22 \cdot 8^{6} & - & 19 \cdot 6^{4} \\ 2 & 22 \cdot 4^{4} & 24 \cdot 1^{2} & 22 \cdot 0^{4} \\ 3 & 22 \cdot 0^{4} & 21 \cdot 8^{2} & 18 \cdot 4^{4} \\ 4 & 16 \cdot 1^{4} & 16 \cdot 0 & - \\ 5 & 11 \cdot 4^{2} & - & 10 \cdot 2^{2} \\ 6 & 11 \cdot 0^{2} & 11 \cdot 1 & 8 \cdot 8^{2} \\ 7 & 10 \cdot 6^{2} & 11 \cdot 8 & 8 \cdot 2^{2} \\ 8 & 7 \cdot 8^{2} & - & 7 \cdot 8 \\ 9 & 6 \cdot 3 & - & 6 \cdot 6 \\ 10 & 5 \cdot 2 & 5 \cdot 2 & 4 \cdot 4 \\ 11 & 3 \cdot 2 & - & 2 \cdot 0 \\ 12 & 3 \cdot 0 & 3 \cdot 0 & 2 \cdot 0 \\ B & & & \\ 13 & & & \\ 14 & 24 \cdot 0^{3} & - & 20 \cdot 8^{3} \\ 15 & 21 \cdot 8^{4} & 21 \cdot 0^{2} & 15 \cdot 6^{4} \\ 16 & 19 \cdot 9^{3} & 21 \cdot 6^{2} & 15 \cdot 9^{3} \\ 17 & 17 \cdot 1^{2} & - & 12 \cdot 8^{2} \\ 18 & 16 \cdot 3^{4} & 15 \cdot 2 & 14 \cdot 7^{4} \\ 19 & 7 \cdot 1 & 7 \cdot 2 & 5 \cdot 5 \\ 20 & 4 \cdot 2 & - & 3 \cdot 3 \\ 21 & 3 \cdot 7 & - & 3 \cdot 2 \\ 22 & 2 \cdot 2 & - & 1 \cdot 5 \\ & 1 \cdot 7 & - & 1 \cdot 3\end{array}$

by the present method, that of Malloy \& Evelyn (1937) as representing one of the most widely used of the non-precipitation methods, and that of King \& Coxon (1950) as an example of a recent type of precipitation technique.

\section{DISCUSSION}

The technical procedure calls for a brief comment upon the choice of reagents. Urea-ethanol is used in place of ethanol alone in developing the total reactivity of the bilirubin present for two reasons. Urea itself has been shown by Gray \& Whidborne (1947) to have an accelerating action upon indirect bilirubin, and it can be safely used up to the concentration employed in the present method, though greater concentrations impede the reaction. Moreover, the denaturation effect on the serum protein of urea-ethanol is different from that of ethanol alone, for any precipitated protein formed at that stage is more readily dissolved in the phenol solution used later. The ethanolic concentration present at the colour-development stage is well in excess of $50 \%$ and therefore adequate according to our own experience and that of Malloy \& Evelyn as to the requisite minimum ethanol concentration for full colour production. In all cases that have been investigated a 10-min. period has been found ample for maximum colour development.

\section{Table 5. Estimations of bilirubin in 'indirect' and 'delayed direct' sera}

(Indices indicate dilution factors. $A$, read on Biochem absorptiometer, Chance filter OG 1; $B$, read on Spekker absorptiometer, Ilford filter 604, except for the Malloy \& Evelyn (1937) method when 605 filter was used.)

\begin{tabular}{|c|c|c|c|}
\hline Case & $\begin{array}{c}\text { Present } \\
\text { method } \\
(\mathrm{mg} . / 100 \mathrm{ml} .)\end{array}$ & $\begin{array}{c}\text { Malloy \& } \\
\text { Evelyn }(1937) \\
\text { method } \\
(\mathrm{mg} . / 100 \mathrm{ml} .)\end{array}$ & $\begin{array}{l}\text { King } \\
\text { Coxon (1 } \\
\text { methe } \\
\text { (mg./100 }\end{array}$ \\
\hline & \multicolumn{3}{|c|}{ Series $A$} \\
\hline 1 & $1 \cdot 82$ & - & \\
\hline 2 & $1 \cdot 10$ & - & \\
\hline 3 & $0 \cdot 83$ & 一 & \\
\hline 4 & $0 \cdot 69$ & - & \\
\hline Horse serum 1 & 3·39 & 一 & \\
\hline Horse serum 2 & $1 \cdot 32$ & - & \\
\hline \multicolumn{4}{|c|}{ Series $B$} \\
\hline 5 & $23 \cdot 7^{4}$ & $22 \cdot 7$ & $20 \cdot 6$ \\
\hline 6 & $10 \cdot 2^{2}$ & $10 \cdot 6$ & $9 \cdot 3$ \\
\hline 7 & $7 \cdot 4$ & $7 \cdot 8$ & $7 \cdot 0$ \\
\hline 8 & $6 \cdot 1$ & $6 \cdot 6$ & $5 \cdot 5$ \\
\hline 9 & $2 \cdot 55$ & - & \\
\hline 10 & $1 \cdot 04$ & - & \\
\hline 11 & 0.69 & - & \\
\hline
\end{tabular}

The neutral citrate solution added prior to the phenol solution could be omitted in dealing with the great majority of sera, but, in its absence, some specimens of exceptionally low buffering capacity tended to give colours of a slightly bluer tint than did normally buffered sera, and the results were, therefore, rendered less reliable. Similarly, the addition of the pure chloroform might also be considered dispensable in a general way. It has been retained throughout, not only because it accurately balances in the estimation the conditions of the calibration method, but because, with specimens that are lipaemic, its presence gives a rather brighterfinal solution.

In that strong phenol solutions require special care in handling, alternative reagents that have a marked solvent effect upon protein, e.g. concentrated thiocyanate and aqueous urea, have been examined, but have been found less effective in providing high clarity than phenol.

Methanol has also been investigated as an alternative to ethanol in the urea-ethanol solution. As in 
the Malloy \& Evelyn (1937) method it gives a rather greater amount of colour for a given concentration of bilirubin (Moreland, O'Donnell \& Gast, 1950) and rather less protein precipitation in the colour development stage, but offers no advantage in reaching final clarity.

While serum is preferred for this form of analysis, plasma can be used with almost the same precision in the estimations. There is a tendency for the final solution in the case of plasma to have a very slightly lower degree of optical clarity. This is balanced by the corresponding blank solution, so that the colorimeter readings are not affected, and in general the solutions with plasma are clearer than those obtained by other non-precipitation techniques which use only serum.

In regard to the comparative results of the three methods employed, it is scarcely to be expected that they should provide identical results. Although the Malloy \& Evelyn method and the present method are fundamentally the same in that neither entails loss by separation of protein, the calibration method is a little different in the two cases. Malloy \& Evelyn standardize with pure bilirubin solutions without relation to blanks incorporating unchanged bilirubin, whereas the unchanged pigment necessarily appears in the blanks corresponding to the serum tests. In the present method, unchanged bilirubin appears in both the blank of the standardization technique and that of the test.

The King \& Coxon method does not involve any blank preparation either in calibration or in serum analysis, for the precipitation of protein takes with it any constituent likely to give an appreciable degree of light absorption other than that due to azobilirubin. In a blank designed to run parallel with their rest method, a high proportion of unchanged bilirubin is absorbed on the protein precipitate, so there cannot in practice be a blank comparable to that employed in the present method.

These considerations would always account for minor differences in the values obtained by the different methods, but reference to Table 4 shows that, while closely comparable results are obtained between the present method and that of Malloy \& Evelyn, the King \& Coxon method often gives figures in the direct-reacting sera which lag substantially behind. They represent, however, a much nearer approach to the figures of the non-precipitation methods than those obtained by earlier precipitation techniques, for losses of up to $50 \%$ of colour were encountered in the method of Haslewood \& King, when that was compared with the Malloy \& Evelyn procedure (Gray \& Whidborne, 1946). In the case of indirect-reacting sera, the results of King \& Coxon and those of the present method are seen to be in closer agreement.
In that King \& Coxon use an artificial standard of methyl red solution, whereas in the present method as well as in that of Malloy \& Evelyn we have employed a preparation of bilirubin, reference should be made to the relationship between the two standards. Substituting in the King \& Coxon technique $1 \mathrm{ml}$. of $3 \cdot 6 \% \mathrm{Na}_{2} \mathrm{HPO}_{4} \cdot 12 \mathrm{H}_{2} \mathrm{O}$ for serum, adding to it $0.4 \mathrm{ml}$. of chloroform containing $0.04 \mathrm{mg}$. of bilirubin, then adding $0.5 \mathrm{ml}$. of their van der Bergh reagent, and finally making up to a volume of $10 \mathrm{ml}$. with $85 \%$ ethanol, we obtained an absorptiometer reading equal to $99 \%$ of that of the methyl red standard. With $1 \mathrm{ml}$. of our acid citrate buffer in place of serum and other reagents used as above, the reading was $101 \%$ of the same standard. We are therefore satisfied that we are attaching no unfair disadvantage to the recorded values for the King \& Coxon method in assessing them in terms of their artificial standard solution.

The main advantages of the present method over that of Malloy \& Evelyn are that the final colour is observed in clearer solution, and that, for a given concentration of serum bilirubin, the colours are much more intense, enabling more accurate readings to be made at much lower levels of bilirubin concentration. The method is, therefore, especially well suited to studies such as those of bilirubin threshold, and of the removal from the blood of injected bilirubin. In conjunction with appropriate precipitation methods, it is likely to facilitate further investigation into the cause of discrepancies which exist between the results of the two types of method of estimation. It may also be easily adapted to provide the means of following the rates of reaction of the different types of bilirubin present simultaneously in blood, and thereby contributed further to the understanding of the physico-chemical nature of the circulating bilirubin.

\section{SUMMARY}

1. A method is described for determining bilirubin in serum which does not involve separation of protein. Colour is developed by the van den Bergh reagent in the presence of a urea-ethanol solution, and clarity achieved by use of phenol, following the inactivation of excess diazonium compound.

2. The results achieved by the present method are in closer alinement with those of Malloy \& Evelyn (1937) than with those of King \& Coxon (1950).

3. As compared with the method of Malloy \& Evelyn, the present technique is capable of giving greater accuracy at low bilirubin levels.

We are grateful to Dr P. L. Mollison, Director of the Medical Research Council Blood Transfusion Research Unit, and to Prof. E. J. King, of the Postgraduate Medical School of London, for placing at our disposal samples of cord blood of jaundiced infants. 


\title{
REFERENCES
}

Gray, C. H. \& Whidborne, J. (1946). Biochem. J. 40, 81.

Gray, C. H. \& Whidborne, J. (1947). Biochem. J. 41, 155.

Haslewood, G. A. D. \& King, E. J. (1937). Biochem. J. 31, 920.

Jendrassik, L. \& Cleghorn, R. H. (1936). Biochem. Z. 289, 1.

King, E. J. \& Coxon, R. V. (1950). J. clin. Path. 3, 248.

Lees, H. (1950). Biochem. J. 47, xliv.
Lemberg, R. \& Legge, J. W. (1949). Hematin Compounds and Bile Pigments. New York: Interscience.

Malloy, H. T. \& Evelyn, K. A. (1937). J. biol. Chem. 119, 481.

Moreland, F. B., O'Donnell, W. W. \& Gast, J. H. (1950). Fed. Proc. 9, 207.

Rappaport, F. \& Eichhorn, F. (1943). Lancet, 1, 62.

Thannhauser, J. S. \& Andersen, E. (1921). Dtsch. Arch. klin. Med. 137, 179.

\section{Lipovitellin}

\section{THE INFLUENCE OF WATER ON THE STABILITY OF LIPOVITELLIN AND THE EFFECTS OF FREEZING AND OF DRYING}

\author{
By C. H. LEA AND J. C. HAWKE \\ Low Temperature Station for Research in Biochemistry and Biophysics, University of Cambridge, \\ and Department of Scientific and Industrial Research
}

\section{(Received 4 January 1952)}

The lipid-protein complexes (lipoproteins) of tissues are usually said to be decomposed by freezing or drying; in fact, modern theories of their structure generally include water as an integral part of the molecule (e.g. Dervichian, 1949). Little or no quantitative information on the subject has, however, been published and, in view of the increasing tendency towards preserving sensitive biological materials and foods in the frozen or dried state, an investigation of the effects on a lipoprotein of freezing and of drying has been carried out. Lipovitellin from egg yolk was chosen as experimental material for reasons already given (Lea \& Hawke, 1951).

Available information on the stability of lipovitellin is conflicting. Chargaff (1942) stated that a suspension of the lipoprotein lost some of its dispersibility in sodium chloride solution on freezedrying. Moran (1925) observed that a solution of 'lecithovitellin' in the minimum concentration of sodium chloride deposited solid on freezing and thawing. Fevold \& Lausten (1946) stated that 'lipovitellinin', a lipoprotein fraction from egg yolk containing 36-41 \% lipid, was not, by freeze-drying, rendered insoluble in sodium chloride solution saturated with ether, but that its dispersibility disappeared on standing. No information was given as to whether or not any free lipid was split off from the protein during freezing, drying or storage, and in none of these cases was the moisture content of the dried material or the conditions of freezing and thawing defined, nor were any quantitative data recorded on the effects observed. It is, however, of considerable practical interest that commercial spray-dried egg, which has a greatly inferior aerating power to fresh egg, yields up much more of its fat on extraction with cold light petroleum than does fresh egg (Brooks \& Hawthorne, 1944).

The present paper deals with some of the properties of lipovitellin in relation to the effects of freezing and drying and of storage in the frozen and dried states.

\section{METHODS}

Preparation of lipovitellin. Lipovitellin was prepared as previously described (Lea \& Hawke, 1951) except that before the final dialysis any material which was not dispersible in $10 \%(\mathrm{w} / \mathrm{v}) \mathrm{NaCl}$ saturated with ether was separated and discarded. It was found that if the final dialysis through cellulose at $0-2^{\circ}$ was continued for longer than $24 \mathrm{hr}$. it became impossible, with the means available, to centrifuge down the suspended lipoprotein. The lipoprotein suspension was therefore centrifuged after dialysis for $24 \mathrm{hr}$. and the concentrated product subjected to continued dialysis with agitation from narrow cellulose sacks for a further $48 \mathrm{hr}$. at $0^{\circ}$.

In some preparations, $50 \%(\mathrm{w} / \mathrm{v})$ sucrose was dissolved in the aqueous phase to protect the lipoprotein from denaturation by ether (Bate-Smith, 1935). This precaution could not be taken, however, in the first ether extraction of the yolk because of increased difficulty with emulsification, and was omitted from the final reprecipitation to avoid the lengthy dialysis necessary to remove the last traces of sugar from the thick lipoprotein suspension. Under these conditions, the use of sucrose resulted in no improvement in the yield or solubility of the preparation. 